\title{
Cydalima Perspectalis Walker (Lepidoptera, Crambidae) a New Dangerous Pest Report on Buxus Sempervirens in Cluj Area
}

\author{
Ion OLTEAN ${ }^{1}$, Ionuț HULUJAN ${ }^{1}$, Ioana HULUJAN ${ }^{1}$, Mircea VARGA ${ }^{1}$, Ștefania TÖTÖS ${ }^{2}$, Teodora \\ FLORIAN ${ }^{1 *}$ \\ ${ }^{1}$ Faculty of Agriculture, University of Agricultural Sciences and Veterinary Medicine, Str. Mănăştur, Nr. 3-5, \\ 400372, Cluj-Napoca, România \\ ${ }^{2}$ UBB Cluj-Napoca, România \\ *Corresponding author:florian.teodora@yahoo.com
}

Bulletin USAMV series Agriculture 74(1)/2017

Print ISSN 1843-5246; Electronic ISSN 1843-5386

DOI 10.15835/buasvmcn-agr: 12655

\begin{abstract}
In landscaping, one of the frequently used plants is Buxus sempervirens $\mathrm{L}$. The aesthetic value of these plants are often affected by the pests species that attack the leaves. The main species that attacks the Buxus spp. plants are: Monarthropalpus buxi Geoff., Psylla buxi L. and Cydalima perspectalis Walker. The attack of these species cause the drying of the plants.The Box Tree Moth, Cydalima perspectalis Walker., is a new species, on the European continent, being first recorded în 2006. In Romania, this species was reported in 2010, near Bucharest, from where it has been spread throughout the country. In Cluj has been reported in 2015. For establishing some control strategies, for this, it is necessary to know the bioecology of this species, depending on the specific environmental conditions of each area where the attack is present. In 2016 we have started the investigations to study the biological cycle, in Cluj area. The investigations were conducted in the laboratory and on the campus of UASVM Cluj-Napoca. In the investigated area, the species develops two full generations, and the third generation is partial. The adults of hibernating generation fly in the first decade of June until the first decade of July. Summer generation adults fly from the first decade of August, creating the second generation and the adults who establish the third generation (partial generation) fly in the second half of September. The incubation is between 5-6 days. Larval stage is between 29-38 days, pupal stage last from 10 to 14 days.
\end{abstract}

Keywords: Cydalima perspectalis, damage level, Buxus sempervirens L. life cycle

\section{INTRODUCTION}

In Cluj area, until recent years Buxus sempervirens (European box, or boxwood) plants were frequently attacked by Monarthropalpus buxi Geoff., and also by Psylla buxi L., species that strongly affected the aesthetic value of the plants (Soporan et al., 2012). Since 2015 în this area was reported, another species, The Box Tree Moth, Cydalima perspectalis Walker. This is a extremely dangerous pest, due to the rapid spread and aggressiveness with which attack the plants.
This species belongs to the Lepidoptera order, family Crambidae and it originated in the East Asia (India, China, Korea, Taiwan, Japan and the Russian Far East) (Krüger, 2008; Leraut, 2012). In the scientific literature and on websources, this species is found in various synonymies, these being: Cydalima perspectalis Walker, 1859; Diaphania perspectalis Walker, 1859; Glyphodes albifuscalis Hampson, 1899; Glyphodes perspectalis Walker, 1859; Neoglyphodes perspectalis Walker, 1859; Palpita perspectalis Walker, 1859; Phacellura 
advenalis Lederer, 1863; Phakellura perspectalis Walker, 1859 (Maruyama, 1993; Maruyama and Shinkaji, 1987, 1991, 1993; Kawazu et al., 2007; Zhou et al., 2005; Krüger, 2008; Park, 2008; Feldtrauer et al., 2009; Mitchell, 2009; Marja et al., 2010; MALLY and NUSS, 2010; Kim and Park, 2013).

In Europe it was for the first time reported in 2006, in southwestern Germany, being introduced with infested buxus cuttings (Krüger, 2008). Then this species has spreaded rapidly in the other European countries. In 2007 it was reported in Switzerland (Billen, 2007; Käppeli, 2008), in Netherlands (Muus et al., 2009; Van Der Straten and Muus 2010); in 2008 it has entered in Austria (Rodeland, 2009; Perny, 2010), France (Feldtrauer et al., 2009; Marja et al., 2010; Brua, 2013), Slovenia (Seljak, 2012; Raspudić et al., 2014), United Kingdom, Ireland (Mitchell, 2009; Salisbury et al., 2012); 2010 in Liechtenstein (Slamka, 2010), Belgium (Casteels et al., 2011), Italy (Tantardini et al.,2012; Bella, 2013; Governatori, 2013); Hungary in 2011 (Sáfián and Horváth, 2011; Szabolcs and Bálint, 2011; Szabóky, 2012), Czech Republic (Šumpich, 2011), Turkey (Hizal, 2012; Hizal et al., 2012); in 2012. it was reported in Croatia (Koren and Črne 2012; Matošević, 2013); in the year 2013 in Slovakia (Pastorális et al., 2013), Czech Republic (Proklov and Karayeva, 2013); Southern Russia (Karpun, 2013) and Denmark (Hobern, 2013), and starting with 2014 is present in Spain (Pérez-Otero et al., 2014; Pino Pérez and Pino Pérez, 2014), Bulgaria (Beshkov et. al., 2015), Montenegro (Ostojić et. al., 2015), Bosnia and Herzegovina (Ostojić et. al., 2015), Serbia (Stojanović et. al., 2015) and Greece (Strachinis et. al., 2015).

Corroborating the growing trend of global temperatures and ecological plasticity of this species and the fact that it is a polivoltin species, we can expect an expansion of the spreading area to the northern limit of Europe (IPPC, 2014; Leuthardt and Ramin, 2011; Nacambo, 2012; Nacambo et al., 2014).

In Romania the species was reported in 2010 in Bucharest area (Iamandei, 2010), and then the area was continuously expanded (Székely et al., 2011; Gutuie et al., 2014; Skolka and Zaharia, 2014; Fora and Posta, 2015; Bunescu and Florian, 2016).

The larvae of this species feed on leaves of different Buxus varieties: Buxus microphylla,
B. microphylla var. insularis, $B$. sempervirens, $B$. colchica, B. sinica, B. balearica (Korycinska and Eyre, 2009; Leuthardt el al., 2010; Marja et al., 2010; Mally and Nuss, 2010; Székely et al., 2011; Hizal, 2012; Todeschini, 2014). Studies in Europe have shown that the strongest attack occurs on Buxus sempervirens var. Rotundifolia, variety preferred by the females for oviposition (Leuthardt and Baur, 2013; Santi et al., 2013).

In the area of origin this species also attacks the Euonymus japonicus Thunb., E. alata (Thunb) Siebold, Ilex purpurea Hassk., Pachysandra terminalis Siebold \& Zucc. and Murraya paniculata L. (Wang, 2008; Marja et al., 2010; Mally and Nuss, 2010; Bella, 2013).

The adult has a white body, except the head and the terminal part of the abdomen, which are brown. The wings are white with bright shades of purple (especially the fresh specimens). The forewings shows on the costal and posterior margin a wide brownish band. The costal band it shows a white central macula. The hindwings it has also a wide brownish band at the level of posterior margin (Mally and Nuss, 2010; Brua, 2013). Within the population are found also melanic specimens, on which both pairs of wings are brown with a white macula towards costal margin. (Korycinska and Eyre, 2011; Sáfián 2011; Szabóky, 2012).

The eggs are round, with a diameter of approx $0.8-1 \mathrm{~mm}$. At first are pale yellow and around hatching they present a black dot corresponding to the cephalic capsule formation of the larva.

The neonatal larvae, has a length of 1-2 mm, and the final instar larvae reach $35-44 \mathrm{~mm}$. The head is black, shiny, and the body is green. On the dorsal-lateral parts presents two wider strips of black bands bounded by a white thin band. On the back it shows black warts, each of them whit a white basal macula. It shows hairs all over the body.

Pupa has a length between $1.5-2 \mathrm{~cm}$. In the beginning it is green with dark stripes on the dorsal surface, and the late development pupa is brown, with darker areas corresponding to the future adult brown bands wing. Pupa is protected by a silk white cocoon, hidden among the infested leaves and branches.

This is a polivolitin species, the number of generations is in line with the thermal particularities of the area where it is found. In the area of origin it develops 4-5 generations per 
year (Maruyama and Shinkaji, 1987, 1991; Tang et al., 1990; Zhou et al., 2005; Matošević, 2013, Perny, 2010), and on the European continent it develops 2-3 generations, with the possibility that in the warmer areas to develop even the fourth generation (Korycinska and Eyre, 2009; Marja et al., 2010; Leuthardt et al. 2010; Sage and Karl, 2010; Santi et al., 2013; Brua, 2013, 2014). The larvae is the hibernating stage, Often in second or third instar stage, located between two leaves, protected by silky threads (Maruyama and Shinkaji, 1991; Nacambo et al., 2013). The attack continues in the spring and pupation occurs between the attacked leaves and branches. The flight of adults generally occurs at the end of May or beginning of June. Adults have a lively zigzag flight (Brua, 2014). They are able to travel long distances between 5-10 km (Van Der Straten and Muus, 2009; Marja et al., 2010; John and Schumacher, 2013; Brua, 2013). The flight takes place at night and adults show positive phototropism, being attracted by the light sources (Feldtrauer et al., 2009 ; Schmitt and Demergès, 2012; Delmas, 2013; Göttig and Herz, 2014). Females lay their eggs on the back of the leaves in the groups of 10-30 eggs stuck with a mucilaginous substance (Marja et al., 2010; Leuthardt and Baur, 2013; Brua, 2013).

Larval development is phased over an interval between 17-87 days, depending on the temperature (Maruyama and Shinkaji, 1991), 24 days (Park, 2008). The larvae prefer for feeding the older leaves (Leuthardt et al., 2013; Brua, 2013; Santi et al., 2013). Below the attacked plants it can be observed large quantities of droppings (Brua, 2013). Sometimes the population density is very high, causing total defoliation of the attacked plants (Leuthardt and Baur, 2013; John and Schumacher, 2013; Kenis et al., 2013; Brua, 2014; Wan et al., 2014). The larvae of this species are not consumed by the birds due to their content in alkaloids (Leuthardt et al., 2013; Brua, 2013). Pupal stage lasts about 10-14 days (Park, 2008), and the new adults fly from late July to early August (Brua, 2014). During the warmest years, when the species develops three generations, the last adults can be observed even until the beginning of October (Brua, 2014).

Sexual attractant pheromone of the species Cydalima perspectalis Walker, it was identified in 2007, (Z)-11-hexadecenal (Z11-16:Ald), (E)-11hexadecenal (E11-16:Ald), e (Z)-11-hexadecenol
(Z11-16:0H), in a ratio of roughly 5:1.25:1 (Kawazu et al., 2007). Results of the studies concerning the synthesis and use of the sexual pheromones have been communicated by: Kim and Park, 2013; Göttig and Herz, 2014; YueQiu et al., 2015; Martin et al., 2015; Santi et al., 2015).

Regarding this insect pest dynamics, the useful entomofauna has a special and important role, (predators and parasites). There has been performed a series of researches concerning, the identification of useful entomofauna, which can grow on and during different development stages of the species Cydalima perspectalis Walker. Some entomopathogenic nematodes were reported: Steinernema carpocapsae and Heterorhabditis bacteriophora (Choo et al., 1991; Göttig and Herz, 2012; Zhou et al., 2005). Also hymenopteran parasitoids were identified, especially in the area of origin of the box tree moth, some of them are present on the European continent. The most important are: Apanteles glomeratus L. Bracon brevicornis Wesmael, Chelonus tabonus Sonan, Dolichogenidea stantoni Ashmead, Braconidae family (She and Feng, 2006; Zimmermann and Wührer, 2010; Göttig and Herz, 2012, 2014; Brua, 2013; Wan et al., 2014); Apechthis compunctor L., Casinaria sp., Ichneumonidae family (Nacambo, 2012; Wan et al., 2014); Trichogramma brassicae Bezdenko and Trichogramma dendrolimi Matsumura, Trichogrammatidae family (Göttig and Herz, 2012; Herz, 2013; Wan et al., 2014); Brachymeria lasus Walker, family Chalcididae (Wan et al., 2014; Brua, 2013); Tyndarichus species, family Encyrtidae (Wan et al., 2014; Brua, 2013). From Diptera order, family Tachinidae, they were reported Exorista sp., Pseudoperichaeta nigrolineata Walker and Compsilura concinnata Meigen (Shi and Hu 2007; Nacambo, 2012; Wan et al., 2014).

From the predators, the most important species is Vespa velutina Lepeletier (Order: Hymenoptera; Family: Vespidae), also present in Europe (Leuthardt and Baur, 2013; Brua, 2013; Wan et al., 2014).

Among the entomopathogenic agents, it is mentioned: baculovirus isolated from Anagrapha falcifera, nucleopolyhedrovirus (AnfaNPV), Bacillus thuringiensis var. kurstaki, Beauveria bassiana,(Rose et al., 2013; Brua, 2013). 

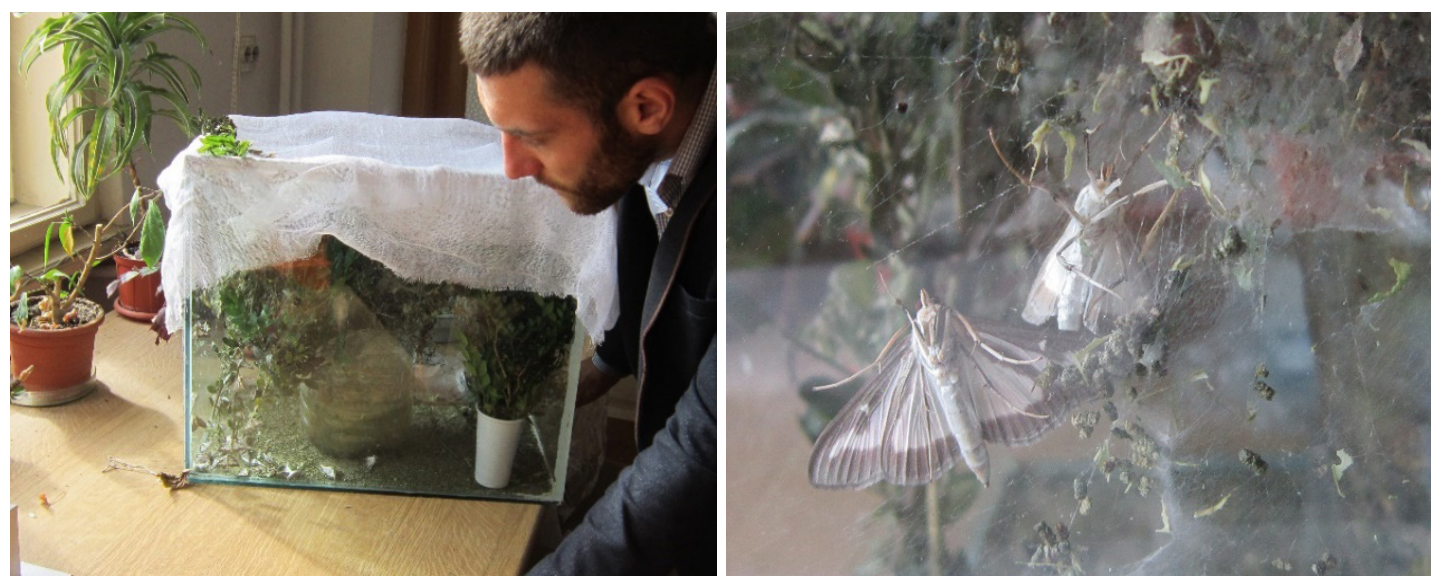

Fig. 1. Cydalima perspectalis Walker in glass breeding cages (foto. Teodora Florian)

\section{MATHERIAL AND METHOD}

In 2016 we performed some investigation regarding the life cycle of Cydalima perspectalis Walker, in Cluj area. The impact of this pest species, on Buxus plants has been also evaluated.

The investigations were carried out both in the laboratory and in the field. Regarding the experience conducted in the laboratory, the biological material was collected from the field before the beginning of the pest activity, placed in insect glass breeding cages, from where, then it was determined the time succession of all development stages (Fig. 1.). For settling the generation's succession, the adults of each generation were transferred to other breeding cages.

Field observations were performed in the area of UASVM Cluj-Napoca Campus Park. The occurrence moment of each development stage was recorded. Simultaneously, the larval attack mode was studied.

\section{RESULTS AND DISCUSSION}

The life cycle of Cydalima perspectalis Walker in 2016 is presented in Table 1.

The hibernating larvae generation have taken their activity in the last days of April. At this time the biological material was layout in the breeding cages from the laboratory. Since the species hibernate in different larval instars, in the laboratory the last active generation of hibernating larvae were reported in 1 June and in the field in June 16.

During the feeding time the larvae give large amounts of excrements, often this element being an indication of the presence of the species, which are easy to observe under the Buxus sp. plants (Fig. 2). Also the signalling of the species can be done when observing the silky treads that the larvae bind the infested leaves (Fig. 3).

In the laboratory the minimum feeding time of the hibernating larvae was 17 days and in the field 29 days. In the laboratory the first pupae were reported in 16 May and in the field in 27 May. The pupae stage occurs between the infested leaves, the pupae being found inside a cocoon (Fig. 4).

In laboratory the pupae were reported between May 16 - June 5 and in the field between May 27 to June 20. The minimum duration of pupal stage was 11 days in the laboratory and 14 days in the field, so the flight of hibernating adults generation was launched on 27 May in the laboratory conditions and on June 10 in the field. The flight of the adults was spread over a period of 20 days in the laboratory conditions (the period 27 May to 15 June) and 30 days in the field (during June 10-July 9).

In the case of the adults obtained in the laboratory conditions they were separated taking under consideration the color of the wings. From the total number of the specimens analyzed $68 \%$ had were from the typical form and $32 \%$ of melanic form (Fig. 5).

Oviposition on the underside of leaves was observed at 2-3 days after the beginning of the flight. Given the gradual emergence of the adults the eggs were reported on a period of approximately three weeks in the laboratory conditions and about four weeks in the field. The incubation period was 6-7 days. In the laboratory conditions the first generation larvae were reported on 6 
Tab. 1. The biological cycle of the species Cydalima perspectalis (Walker, 1859), Cluj-Napoca, 2016

\begin{tabular}{|c|c|c|c|c|}
\hline STAGES & \multicolumn{2}{|c|}{ Laboratory } & \multicolumn{2}{|c|}{ Field (campus USAMV) } \\
\hline \multicolumn{5}{|c|}{ Winter generation } \\
\hline Larva: ranged from & 28.04 & 1.06 & 28.04 & 16.06 \\
\hline the minimum length of the stage & \multicolumn{2}{|c|}{17 days } & \multicolumn{2}{|c|}{29 days } \\
\hline Pupa: ranged from & 16.05 & 5.06 & 27.05 & 20.06 \\
\hline the minimum length of the stage & \multicolumn{2}{|c|}{11 days } & \multicolumn{2}{|c|}{14 days } \\
\hline Adult: ranged from & 27.05 & 15.06 & 10.06 & 9.07 \\
\hline \multicolumn{5}{|c|}{ The first generation } \\
\hline Egg: ranged from & 30.05 & 18.06 & 12.06 & 14.07 \\
\hline incubating & \multicolumn{2}{|c|}{6 days } & \multicolumn{2}{|c|}{7 days } \\
\hline Larva: ranged from & 6.06 & 27.07 & 19.06 & 29.08 \\
\hline the minimum length of the stage & \multicolumn{2}{|c|}{31 days } & \multicolumn{2}{|c|}{38 days } \\
\hline Pupa: ranged from & 7.07 & 31.07 & 27.07 & 12.09 \\
\hline the minimum length of the stage & \multicolumn{2}{|c|}{10 days } & \multicolumn{2}{|c|}{11 days } \\
\hline Adult: ranged from & 17.07 & 5.08 & 7.08 & 20.09 \\
\hline \multicolumn{5}{|c|}{ The second generation } \\
\hline Egg: ranged from & 19.07 & 8.08 & 9.08 & 23.09 \\
\hline incubating & \multicolumn{2}{|c|}{5 days } & \multicolumn{2}{|c|}{6 days } \\
\hline Larva: ranged from & 24.07 & 10.09 & 15.08 & wintering \\
\hline the minimum length of the stage & \multicolumn{2}{|c|}{29 days } & \multicolumn{2}{|c|}{32 days } \\
\hline Pupa: ranged from & 22.08 & 18.09 & 16.09 & $* * *$ \\
\hline the minimum length of the stage & \multicolumn{2}{|c|}{10 days } & \multicolumn{2}{|c|}{12 days } \\
\hline Adult: ranged from & 1.09 & 23.09 & 28.09 & \\
\hline \multicolumn{5}{|c|}{ The third generation } \\
\hline Egg: ranged from & 3.09 & 25.09 & 30.09 & 17.10 \\
\hline incubating & \multicolumn{2}{|c|}{6 days } & \multicolumn{2}{|c|}{7 days } \\
\hline Larva & 9.09 & vintering & 7.10 & wintering \\
\hline
\end{tabular}
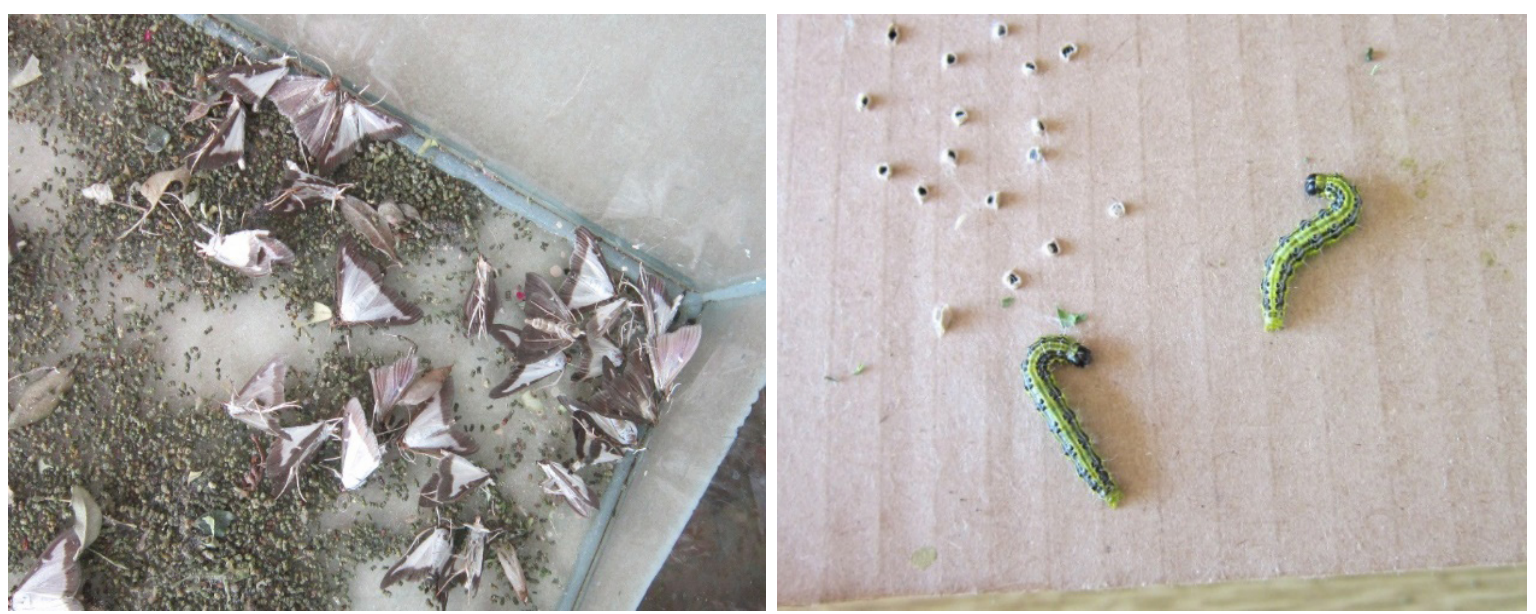

Fig. 2. Excrements of Cydalima perspectalis Walker (foto I. Hulujan) 

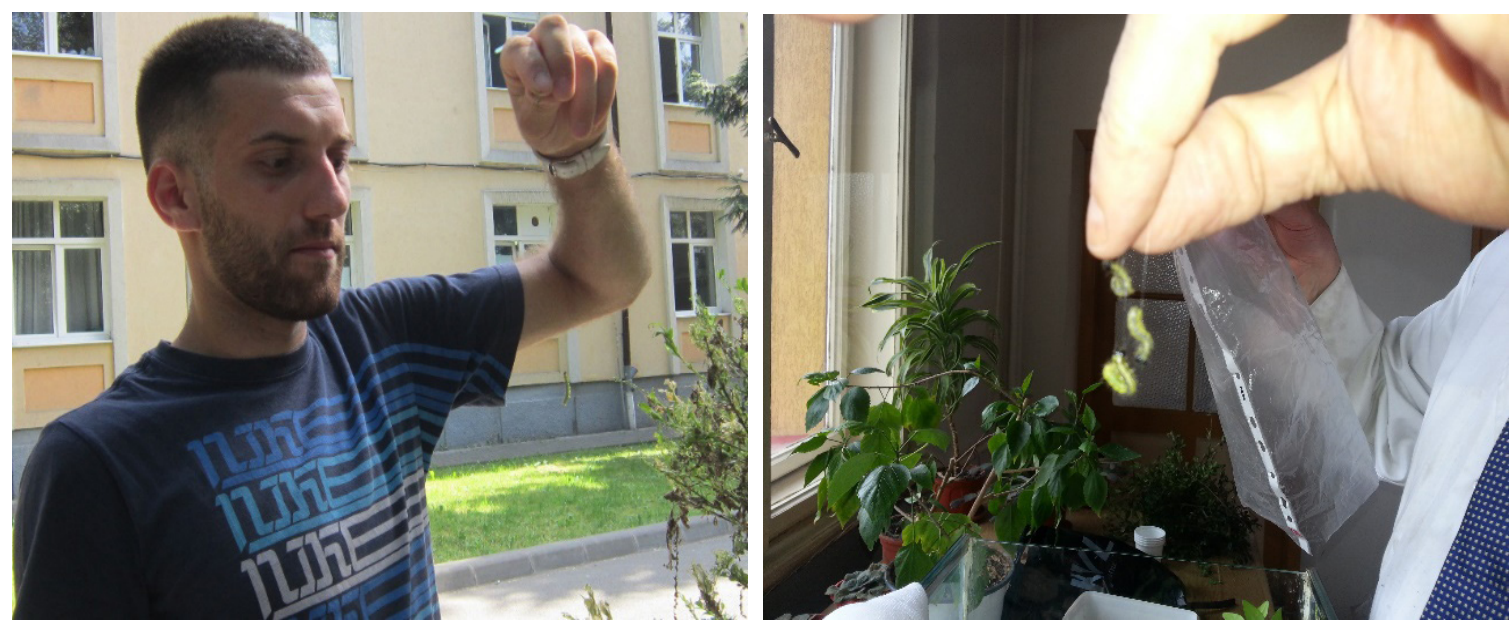

Fig. 3. Silky threads secreted by the larvae of Cydalima perspectalis (foto. Teodora Florian)
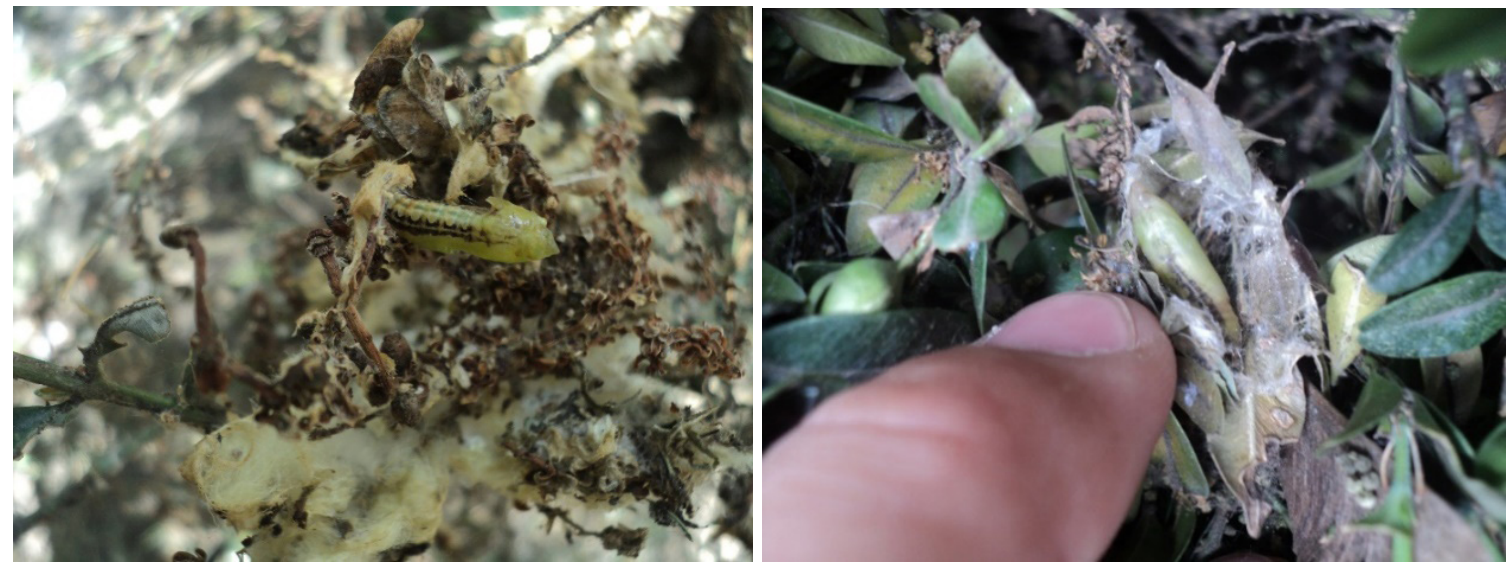

Fig. 4. Pupae of Cydalima perspectalis Walker (foto I. Hulujan)
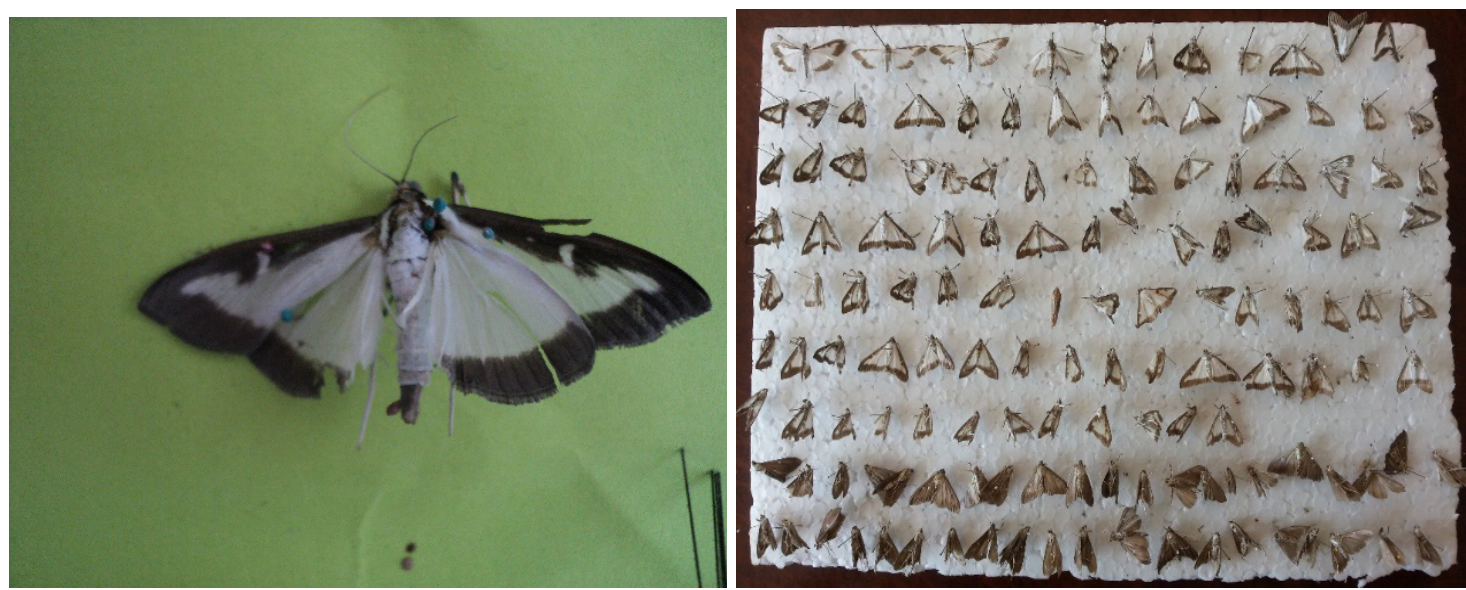

Fig. 5. Adults of Cydalima perspectalis Walker (foto I. Hulujan)

June and in June 19 in the field. The larvae of the first generation have been reported up to 27 July (laboratory) and until the end of August (field).
The young larvae consume the inferior epidermis and the mesophyll of the leaf, but some specimens can be observed on the upper side of 

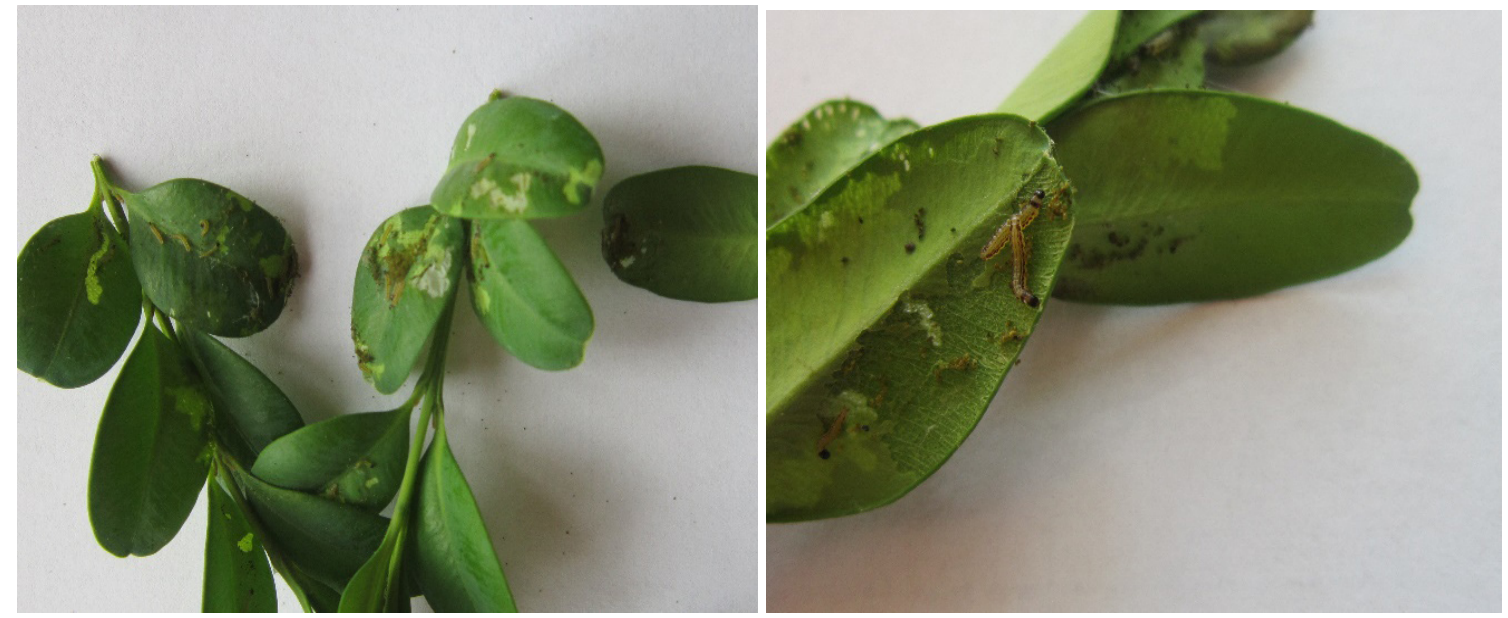

Fig. 6. Attack of Cydalima perspectalis Walker on leaves (foto. Teodora Florian)
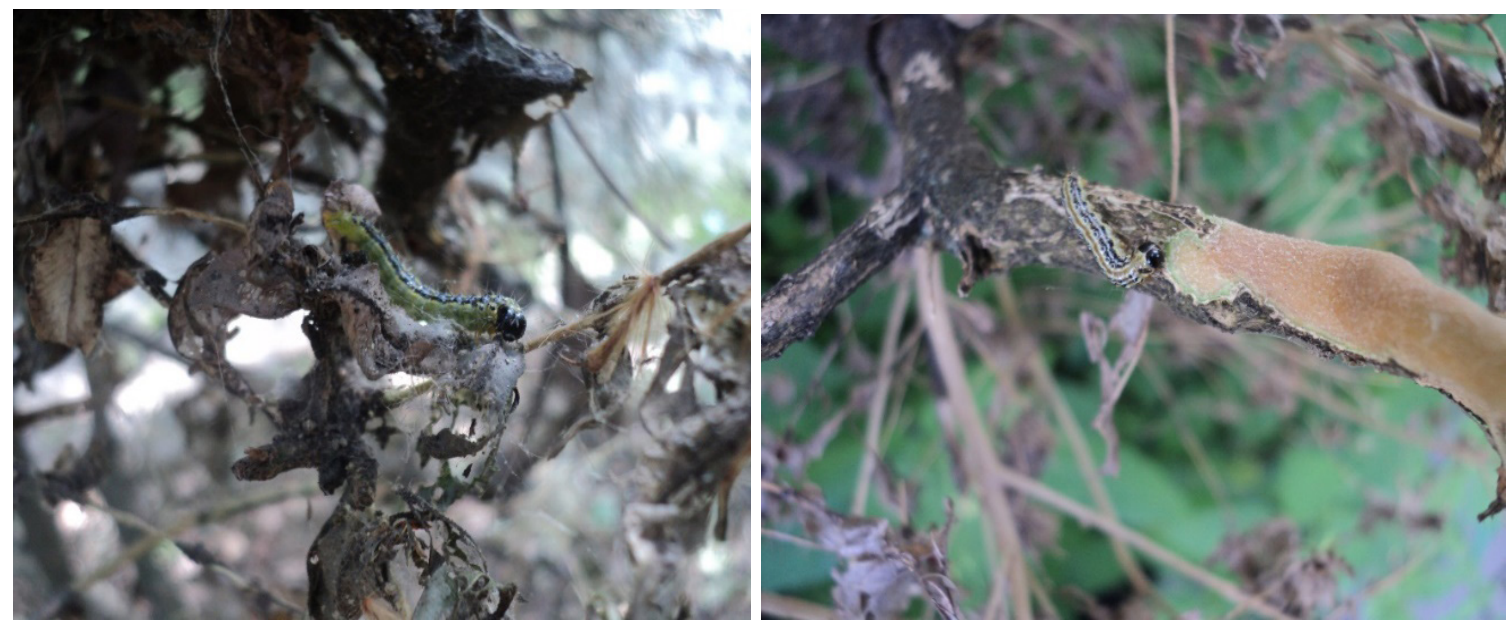

Fig. 7. Attack of Cydalima perspectalis Walker on bark (foto I. Hulujan)

the leaves (Fig. 6). The intense feeding the larvae occurs inside the attacked plant bushes and thus the attack signs are sometimes observed to late and the control is sometimes delayed. Often, the mature larvae attacks the bark on the branches, in which case the drying of these branches occurs faster (Fig. 7). In case of powerful attacks, besides damaging the aesthetic value of plants the plants can be partially or totally destroyed (Fig. 8 and Fig. 9).

The minimum duration of first instar larvae development was 31 days in the laboratory, respectively 38 days in the field, so the pupation period began on July 7 in laboratory conditions and July 27 laboratory field. In laboratory conditions the pupae were present until 31 of July, but the field this stage of development was reported on an extremely large period of time because in the natural environment was observed an overlapping of the developmental generations and the demarcation of the generations was very difficult to perform. For this reason the pupae were reported by the end of September (we reported live pupae even on 19 of November, but subsequent studies are needed in order to see if these pupae will survive the winter conditions).

The minimum duration of the first generation pupal stage was 10 days in the laboratory and 11 days in the field, so the adults of this generation appeared on 17of July in laboratory experiments and in 7 of August in the field. Their flight is largely nocturnal, showing a strong positive phototropism. In the case of the biological material grown in laboratory, the adults of this generation, they flew within a 20 days period and in the field the adults were reported until 20 September (certainly here 

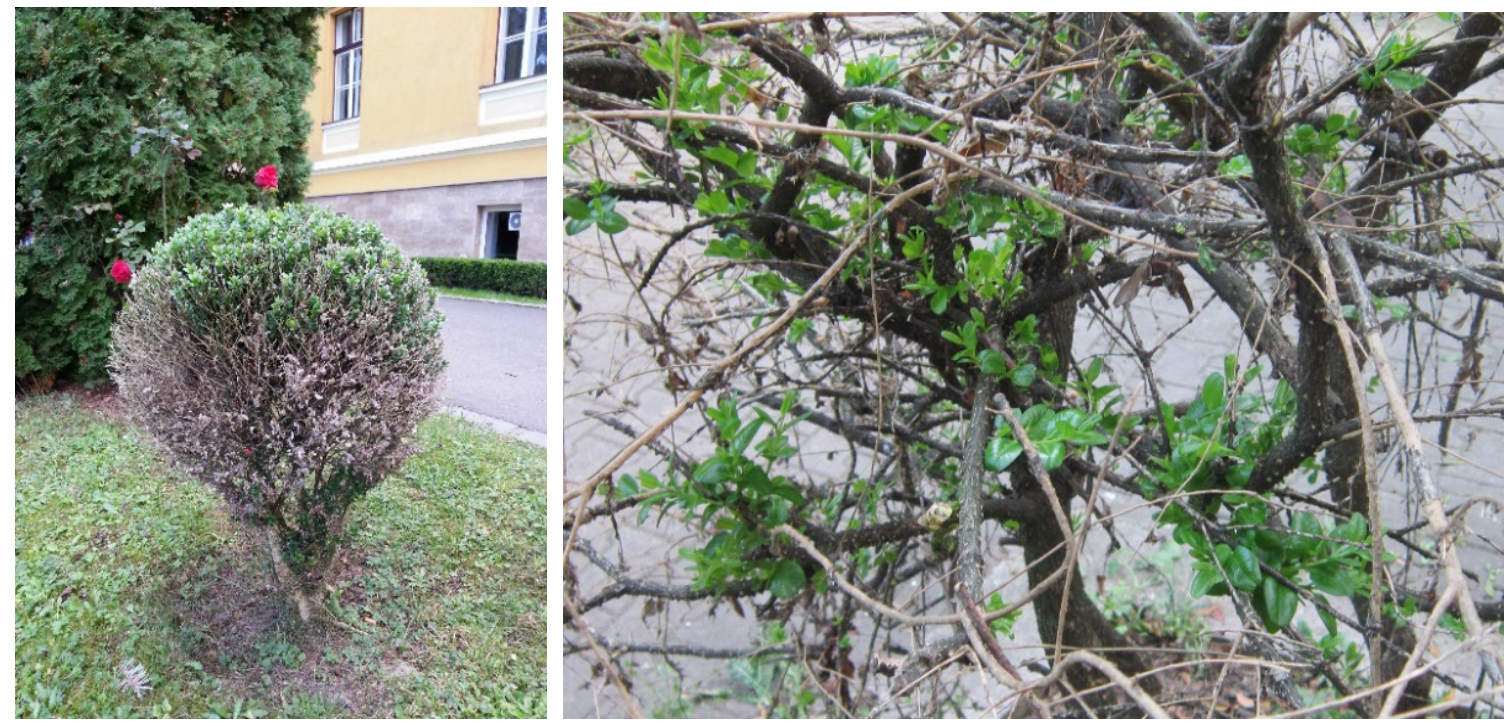

Fig. 8. Attack of Cydalima perspectalis Walker foto I. Hulujan)
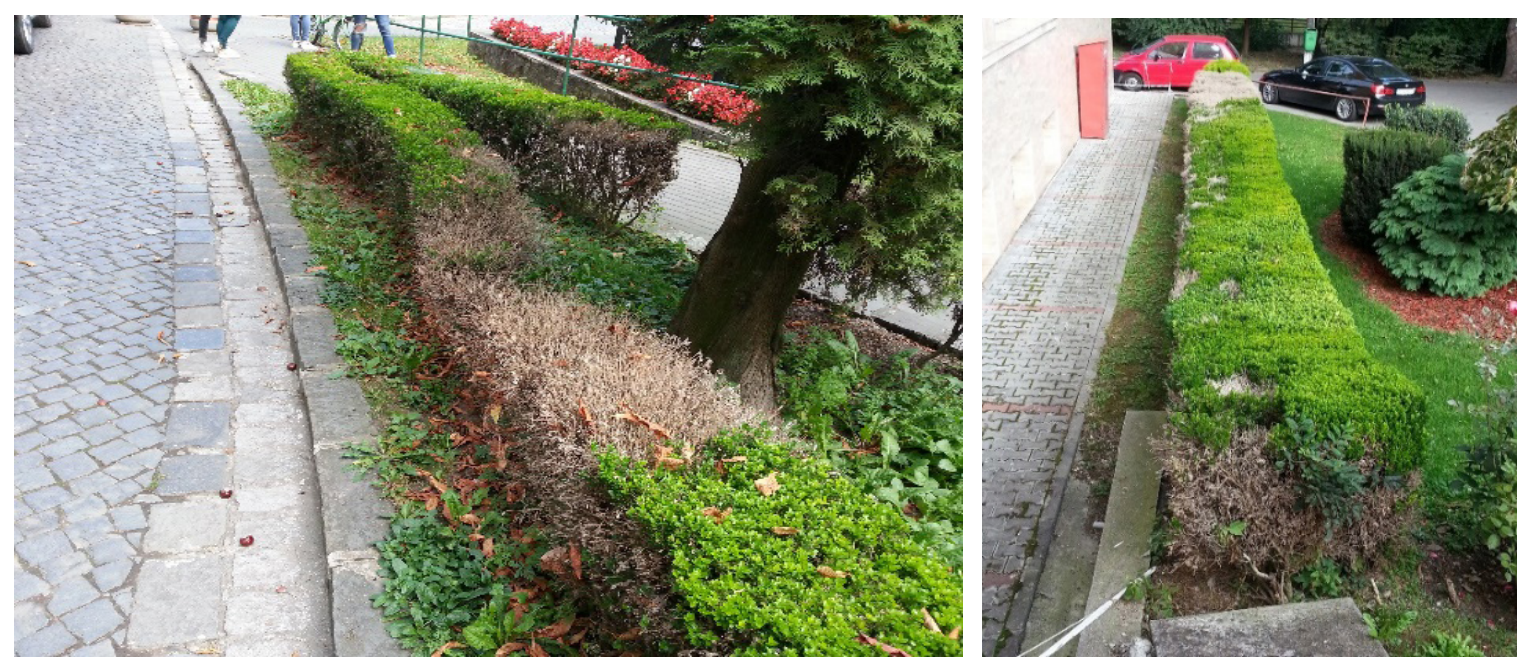

Fig. 9. Attack of Cydalima perspectalis Walker (foto M. Varga)

the flying adult generation partially overlapped with the following generation).

These adults represented the foundation of the second generation. The first egg masses were reported two days after the start of the flight. At this generation the incubation period was between 5-6 days, the larvae of the second generation appeared in 24 of July laboratory and August 15 in the field. In the laboratory the minimum period of development for this stage was 29 days. The adults of the first generation appeared in the laboratory early in August and the period during which the seconds generation larvae were signaled was the first decade of September (thus, a part of the population grown in the laboratory resented only two generations).

In the laboratory, on 22 of August the pupation started for this generation. In the field most of the larvae especially those who hatched in September entered in a hiemal diapause. However, the larvae that hatched in the first half of August continued their development and after almost 32 days they pupated, in 16 of September fresh pupae were signaled.

The adults of the second generation grown in the laboratory began their flight on first of September, they being observed in the breeding cases until September 23, creating this way, the third generation. The larvae of this generation 
hatched starting from $9^{\text {th }}$ of September, so this stage represented the hibernating instar of the species. Also in the field a small part of the population laid the foundations of the third generation, the new egg masses being observed in the last decade of September and the neonate larvae in the first decade of October, larvae that went into hiemal diapause.

\section{CONCLUSIONS}

In Cluj area, Cydalima perspectalis (Walker, 1859) develops two full generations, the third generation is partial.

In field the flight of the hibernating adults generation, occurs between 10.06-9.07.

Depending on the generation the incubation takes place in 5-7 days. days.

Development of the larvae is between 29 to 38

Pupae stage lasts from 10 to 14 days.

\section{REFERENCES}

1. Bella S. (2013). The box tree moth Cydalima perspectalis (Walker, 1859) continues to spread in southern eu- rope: new records for Italy (Lepidoptera Pyraloidea Crambidae). Redia, XCVI: 51-55.

2. Beshkov S., Abadjiev S., Dimitrov D. (2015). Cydalima perspectalis (WALKER, 1859) (Lepidoptera: Pyraloidea: Crambidae: Spilomelinae) - new invasive past moth in Bulgaria, The Entomologist's Record and Journal of Variation, 127 (1): 18-22.

3. Billen, W. (2007). Diaphania perspectalis (Lepidoptera: Pyralidae), a new moth in Europe. Mitteilungen der Entomologischen Gesellschaft Basel, 57 (2/4): 135-137.

4. Brua C. (2013). La pyrale du buis, Cydalima perspectalis (Walker, 1859), espece exotique envahissante, caracteristiques de sa dynamique d'expansion en France et en europe, des degats occasionnes sur les buis (buxus spp) et des strategies de lutte, AFPP - $3^{\mathrm{e}}$ conférence sur l'entretien des espaces verts, jardins, gazons, forêts, zones aquatiques et autres zones non agricoles Toulouse - 15, 16 et 17 octobre 2013

5. Brua C. (2014). La pyrale du buis. Le point sur cette espèce envahissante. Phytoma : la santé des végétaux, $\mathrm{n}^{\circ} 675, \mathrm{p} .16-22$

6. Bunescu H., Florian T. (2016). The Box Tree Moth, Cydalima perspectalis Walker (Lepidoptera: Crambidae: Spilomelinae) a New Invasive Species in Cluj Area (Romania). ProEnvironment/ProMediu, 9(26).

7. Casteels H., Witters J., Vandierendonck S., Van Remoortere L. (2011). First report of Cydalima perspectalis (Lepidoptera: Crambidae) in Belgium.63rd International Symposium on Crop Protection (poster presentation).

8. Choo H.Y., Kaya H.K, Lee, S.M., Kim T.O., Kim J.B. (1991). Laboratory evaluation of entomopathogenic nematodes, Steinernema carpocapsae and Heterorhabditis bacteriophora against some for- est insect pests. Korean Journal of Applied Ento- mology, 30 (4): 227-232.

9. Delmas S. (2013). Observation de Cydalima perspectalis (Walker, 1859) dans l'Hérault et mise au point de sa répartition en France (Lep. Crambidae). Oreina, 22, 44.

10. Feldtrauer J.F., Feldtrauer J.J., Brua C. (2009). Premiers signalements en France de la Pyrale du Buis Diaphania perspectalis (Walker, 1859), espèce exotique envahissante s'attaquant aux Buis (Lepidoptera, Crambidae). Bulletin de la Société Entomolologique de Mulhouse 65(4): 55-58.

11. Fora C.G., Poşta D.S. (2015). Cydalima perspectalis Walk. (Lepidoptera: Crambidae), a dangerous pest of Buxus sempervirens in Timis County, Romania, JOURNAL of Horticulture, Forestry and Biotechnology, Volume 19(3), 26- 31

12. Göttig, S., Herz, A. (2012). Eco-friendly regulation of the box tree pyralid, especially with entomopathogenic nematodes. Berichte aus dem Julius Kühn-Institut, (167), 12.

13. Göttig S., Herz A. (2014). The box tree pyralid Cydalima perspectalis: New results of the use of biological control agents and pheromone traps in the field. Journal of Plant Diseases and Protection, 121:98-99.

14. Governatori G. (2013). La piralide del bosso (Cydalima perspectalis) in Friuli Venezia Giulia. Notiziario Ersa, 1: 35-37.

15. Gutue C., Gutue Minodora, Roșca I. (2014). Crambidae associated with parks and ornamental gardens of Bucharest, Scientific Papers. Series B, Horticulture. Vol. LVIII, 323-326.

16. Herz A. (2013). 1000 Arten für den Pflanzenschutz-die Vielfalt der Nützlinge schützen, fördern und nutzen!. Julius-Kühn-Archiv, (436), 54-61.

17. Hizal R. (2012). Two invasive alien insect species, Leptoglossus occidentalis (Heteroptera: Coreidae) and Cydalima perspectalis (Lepidoptera: Crambidae), and their distribution and host plants in Istanbul province, Turkey. Florida Entomologist, 95(2): 344-349.

18. Hizal E., Kose M., Yesil C., Kaynar D. (2012). The New Pest Cydalima perspectalis (Walker, 1859) (Lepidoptera: Crambidae) in Turkey. Journal of Animal and Veterinary Advances 11(3): 400-403.

19. Hobern D. (2013). - Cydalima perspectalis (Walker, 1859). https://www.flickr.com/photos/dhobern/9418970083/ (accesed 8.08.2016)

20. Iamandei M. (2010). Diaphania perspectalis (Walker, 1859) (Lepidoptera: Crambidae) a new pest of Buxus spp. in Romania. Scient Papers USAMVB Serie B, Vol. 54:787797

21. IPCC. (2014). Climate change 2014. Synthesis Report. Edited by The Core Writing Team; Rajendra K. Pachauri \& Leo Meyer.

22. John Reinhold, Jörg Schumacher, (2013). The Box-Tree Pyralid (Cydalima perspectalis) in the Box-Tree Forest of Grenzach-Whylen, Gesunde Pflanzen, Volume 65, Issue 1, pp 1-6

23. Käppeli F. (2008). Der Buchsbaumzunsler - Im Eiltempo durch Basler Garten. g'plus - die Gärtner-Fachzeitschrift (Zürich) 20: 33.

24. Karpun N.N., Ignatova Ye.A. (2013). The first report about Cydalima perspectalis Walker on Black Sea coast of Russia. 
In Materialy IX mezinarodni vedecko-prakticka conference «Zpravy vedecke ideje-2013». Praha (pp. 29-32).

25. Kawazu K., Honda H., Nakamura S., Adati T. (2007). Identification of sex pheromone components of the box tree pyralid, Glyphodes perspectalis. Journal of Chemical Ecology. 33(10): 1978-1985.

26. Kenis M., Nacambo S., Leuthardt F.L.G., Di Domenico F., Haye T. (2013). The box tree moth, Cydalima perspectalis, in Europe: horticultural pest or environmental disaster? Ed. Aliens - The invasive species bulletin. 33:38-41.

27. Kim J., Park I.-K. (2013). Female sex pheromone components of the box tree pyralid, Glyphodes perspectalis, in Korea: field test and development of film-type lure.Journal of Asia-Pacific Entomology, 16: 473-477.

28. Koren T., Črne M. (2012). The first record of the Box Tree Moth, Cydalima perspectalis (WALKER, 1859) (Lepidoptera, Crambidae) in Croatia., Natura Croatica 21 (2): $507-510$

29. Korycinska A., Eyre D. (2009). Box tree caterpillar, Diaphania perspectalis., The Food and Environment Research Agency FERA, Plant pest factsheet. (http://www. fera.defra.gov.uk/plants/plantHealth/pestsDiseases/ documents/ boxTree-Caterpillar.pdf) [accessed 19.09. 2016]

30. Krüger E.O. (2008). Glyphodes perspectalis (Walker, 1859) - neu für die Fauna Europas (Lepidoptera: Crambidae). Entomologische Zeitschrift 118: 81-83.

31. Leraut P. (2012). Moths of Europe Zygaenids, Pyralids 1, Volume 3, Nap. Editions, 600 pp.

32. Leuthardt L.G.F., Billen W., Baur B. (2010). Ausbreitung des Buchsbaumzünslers Diaphania perspectalis (Lepidoptera, Pyralidae) in der Region Baseleine für die Schweizneue Schädlingsart. Entomo Helvetica, 3: 51-57.

33. Leuthardt F.L.G., Ramin S. (2011). The Box-Tree Pyralid Diaphania perspectalis - Occurrence, Dispersal and Impact of an Invasive Species in Switzerland. - Jahrbuch der Baumpflege, 255-260.

34. Leuthardt F.L.G., Baur B. (2013). Oviposition preference and larval development of the invasive moth Cydalima perspectalis on five European box-tree varieties. Journal of Applied Entomology, 137:437-444.

35. Leuthardt F.L.G., Glauser G., Baur B. (2013). Composition of Alkaloids in Different Box Tree Varieties and their Uptake by the Box Tree Moth Cydalima perspectalis, Chemoecology 23(4): 203-212.

36. Mally R., Nuss M. (2010). Phylogeny and nomenclature of the box tree moth, Cydalima perspectalis (Walker,1859) comb. n., which was recently introduced into Europe (Lepidoptera: Pyraloidea: Crambidae: Spilomelinae). European journal of entomology, 107 (3), 393-400.

37. Marja J. Van der Straten \& Tymo S.T. Muus M. (2010). The box tree pyralid, Glyphodes perspectalis (Lepidoptera: Crambidae), an invasive alien moth ruining box trees, Proc. Neth. Entomol. Soc. Meet. - Volume 21, 107-111.

38. Martin J.C., Brinquin Anne-Sophie, Morel Estelle, Tabone Élisabeth, Guérin Maxime (2015). Vers un outil de biocontrôle innovant et performant controle le pyrale du buis, Phytoma, no 680: 41-44

39. Maruyama T., Shinkaji N. (1987). Studies on the life cycle of the box-tree pyralid, Glyphodes perspectalis (Walker)
(Lepidoptera: Pyralidae) I. Seasonal adult emergence and developmental velocity. Japanese Journal of Applied Entomology and Zoology 31: 226-232.

40. Maruyama T., Shinkaji N. (1991). The life cycle of the boxtree pyralid, Glyphodes perspectalis (Walker) (Lepidoptera: Pyralidae) II. Developmental characteristics of larvae. Japanese Journal of Applied Entomology and Zoology 35: 221-230.

41. Maruyama T., Shinkaji N. (1993). Life cycle of the box-tree pyralid, Glyphodes perspectalis (Walker) (Lepidoptera: Pyralidae) III. Photoperiodic induction of larval diapause. Japanese Journal of Applied Entomology and Zoology 37: 45-51.

42. Maruyama T. (1993). Life cycle of the box-tree pyralid, Glyphodes perspectalis (Walker) (Lepidoptera: Pyralidae). IV. Effect of various host plants on larval growth and food utilization. Japanese J. Appl. Entomol. Zool. 7(3): 117-122

43. Matošević D. (2013). Box Tree Moth (Cydalima perspectalis, Lepidoptera; Crambidae), new invasive insect pest in Croatia. South-East Eur For 4 (2): 89-94.

44. Mitchell A. (2009). Box tree moth Diaphania perspectalis (Walk.) - a new pyralid moth to Britain and Ireland. Atropos 36: 17-18

45. Muus, T.S.T., Van Haaften, E-J., Van Deventer, L.J. (2009). De buxus mot Palpita perspectalis (Walker) in Nederland (Lepidoptera: Crambidae). Entomologische Berichten, Amsterdam 69 (2): 66-67.

46. Nacambo S. (2012). Parasitisme, developppement, modele climatique et impact de Cydalima perspectalis en Europe. MSc-thesisUniversity of Neuchatel, Switzerland.

47. Nacambo S., Leuthardt F.L.G., Wan H., Li H., Haye T., Baur B., Weiss R.M., Kenis M. (2014). Development characteristics of the box-tree moth Cydalima perspectalis and its potential distribution in Europe. Journal of Applied Entomology. 138(1-2):14-26

48. Ostojić I. Van Zovko, M., Petrović, D., Elez D. (2015). New records of Box Tree Moth Cydalima perspectalis (Walker, 1859) in Bosnia and Herzegovina. - Radovi Poljoprivredno-prehrambenog fakulteta, Univerziteta $\mathrm{u}$ Sarajevu [Works of the Faculty of Agricultural and Food Sciencies, University of Sarajevo], LX (65/1): 139-143

49. Park I. K. (2008). Ecological characteristic of Glyphodes perspectalis. Korean journal of applied entomology, 47(3), 299-301.

50. Pastorális G., Elsner G., Kopeèek F., Kosorin F., Laštůvka A., Lendela A., Liška J., Nimy J., Richter I., Stefanovie R., Šumpich, J., Tokar Z. (2013). Fourteen Lepidoptera species new to the fauna of Slovakia. Folia Faunistica Slovaca, 18: $1-12$.

51. Perny B. (2010). Mass outbreak of box tree pyralid Diaphania perspectabitis in the East of Austria (in German with English summary). Forstschutz aktuell 50: 17-19

52. Pérez-Otero R., Mansilla J.P., Vidal M. (2014). Cydalima perspectalis Walker, 1859 (Lepidoptera, Crambidae): una nueva amenaza para Buxus spp. en la Península Ibérica. Arquivos Entomolóxicos, 10: 225-228.

53. Pino Pérez J.J., Pino Pérez R. (2014). Segunda cita de Cydalima perspectalis (Walker, 1859) (Lepidoptera, Crambidae) para Galicia (NO España), Boletín BIGA, 14, 47-50 
54. Proklov V.V., Karayeva S.Z. (2013). New and interesting Lepidoptera records from Chechen Republic (Russia). Caucasian Entomological Bulletin 9(2): 281-282.

55. Raspudić E., Ivezić M., Brmež M., Maji, I., Sarajlić A. (2014). The Box Tree Moth (Cydalima perspectalis Walker, 1859) new pest of boxwood on the area of Slavonija. In 1 . Hrvatski Simpozij O Invazivnim Vrstama.

56. Rodeland J. (ed.) (2009). Lepiforum: Bestimmung von Schmetterlingen (Lepidoptera) und ihren Präimaginalstadien. http://www.lepiforum.de/ (accesed 8.08.2016)

57. Rose J., Kleespies R.G., Wang Y., Wennmann J.T., Jehle J.A. (2013). On the susceptibility of the box tree moth Cydalima perspectalis to Anagrapha falcifera nucleopolyhedrovirus (AnfaNPV). Journal of Invertebrate Pathology. 113 (3):191-197.

58. Sage W., Karl G. (2010). Der Buchsbaumzünsler Cydalima perspectalis (Walker, 1859) nun auch in Südostbayern. Mitteilungen der Zoologischen Gesellschaft Braunau 10(1):79-85.

59. Salisbury A, Korycinska A, Halstead AJ. (2012). The first occurrence of larvae of the box tree moth, Cydalima pesrpectalis (Lepidoptera: Crambidae) in private gardens in the UK. Br. J. Entomol. Nat. Hist. 25, 1-5.

60. Santi Fabrizio, Paolo Radeghieri, Stefano Maini (2013). Piralide del bosso: all insetto esotico, Adversita delle piante, Novembre 2013, 76-77

61. Santi F., Radeghieri P., Sigurta G. I., Maini S. (2015). Sex pheromone traps for detection of the invasive box tree moth in Italy. Bulletin of Insectology, 68(1), 158-160.

62. Sáfián S., Horváth B. (2011). Box Tree Moth - Cydalima perspectalis (Walker, 1859), new member in the Lepidoptera fauna of Hungary (Lepidoptera: Crambidae). Natura Somogyiensis 19: 245-246

63. Seljak G. (2012). Six new alien phytophagous insect species recorded in Slovenia in 2011. Acta Entomologica Slovenica, 20 (1):31-44.

64. Schmitt R., Demergès D. (2012). Nouvelles observations de Diaphana perspectalis (Walker, 1849) (Lep. Crambidae). Oreina, 19, 5.

65. She D.S, Feng F.J (2006). Bionomics and Control of Diaphania perspectalis (Walker). J. Zhejiang Forest. Sci. Tech. 26, 47-51

66. Shi HZ, Hu KF. (2007). Occurrence regularity and control techniques of Diaphania perspectalis (Walker). Hubei Agric. Sci. 46, 76-78

67. Skolka M., Zaharia R. (2014). Cydalima perspectalis (Lepidoptera: Crambidae) - new invasive species in Constanța, International Zoological Congress of "Grigore Antipa" Museum 19 - 22 November 2014, Book of Abstracts, Bucharest, Ed. Medialux, București, 181-182.

68. Slamka F. (2010). Pyraloidea (Lepidoptera) of Central Europe. František Slamka, Bratislava, $174 \mathrm{pp}$.

69. Soporan Cristina-Rozana, I. Oltean, Teodora Florian (2012). The Monarthopalpus Buxi Species Population Dynamics in Cluj County (Romania), Bulletin UASVM Horticulture, 69(1)/2012, pag. 221-224.

70. Stojanović D.V., Konjević A., Marković M., Kereši T. (2015). Appearance of the box tree moth Cydalima perspectalis
(Walker, 1859)(Lepidoptera, Crambidae) in Vojvodina. Biljni lekar, 43(4), 387-395.

71. Strachinis I., Kazilas C., Karamaouna F., Papanikolaou N.E., Partsinevelos G.K., Milonas P.G. (2015). First record of Cydalima perspectalis (Walker,1859) (Lepidoptera: Crambidae) in Greece. Hellenic Plant Protection Journal 8: 66-72.

72. Szabóky C.S. (2012). New data to the Microlepidoptera fauna of Hungary, part XIV (Lepidoptera: Tineidae, Gracillariidae, Gelechiidae, Crambidae), Folia Entomologica Hungarica, Vol. 73:45-51.

73. Szabolcs S., Bálint H. (2011). Box tree moth - Cydalima perspectalis (Walker, 1959), new member in the Lepidoptera fauna of Hungary (Lepidoptera: Crambidae). - Natura Somogyiensis, 19: 245-246.

74. Székely L., Dincă V., Mihai C. (2011). Cydalima perspectalis (Walker, 1859), a new species for the Romanian fauna (Lepidoptera: Crambidae: Spilomelinae). Bul. inf. Entomol., 22 (3-4): 73-77.

75. Šumpich J. (2011). Motýli Národních park Podyjí a Thayatal, Znojmo. pp. 428.

76. Sun AQ, Zhou XM, Gao QH, (2009). Occurrence regularity and control technology of Diaphania perspectalis (Walker) in Langfang City. North. Horticult. 9, 136-137

77. Tantardini A., Cavagna B., Maspero M. (2012). Una nuova introduzione, Piralide del bosso. Acer, 4, 56-57.

78. Tang, S.J. Qin, H.Z., Sun, W. (1990). Studies on bionomics of Diaphania perspectalis. Journal of Shanghai Agricultural College 8: 307-312.

79. Todeschini Valeria (2014). La piralide del bosso, Intersezioni - Entomologia, 54:1-2.

80. Van Der Straten M.J., Muus T.S.T. (2010). The box tree pyralid, Glyphodes perspectalis (Lepidoptera: Crambidae), an invasive alien moth ruining box trees. Proceedings of the Netherlands Entomological Society Meeting 21: 107111.

81. Wang Y.M. (2000). The biological character and control of a new pest (Diaphania perspectalis) on Murraya paniculata. J. Fujian Forest. Sci. Tech. 35, 161-164

82. Wan H, Haye T, Kenis M, Nacambo S, Xu H, Zhang F, Li H. (2014). Biology and natural enemies of Cydalima perspectalis in Asia: Is there biological control potential in Europe? Journal of Applied Entomology, 138(10):715722.

83. Zhou W., Xia C.-Y., Sun X.-Q., Zhu B., Liu X.-P., Liu Z.-C. \& Wang Y. (2005). Studies on the biological characteristics and control of Diaphania perspectalis Walker. J. Shanghai Jiaotong Univ. Agric. Sci. 23: 52-56.

84. Zimmermann O., Wührer B. (2010). Initial investigations on the ability of the indigenous larval parasitoid Bracon brevicornis to control the box-tree pyralid Diaphania perspectalis in Germany. DGaaE-Nachrichten, 24, 25-26.

85. YueQiu H., ShuYou C., YongJun D. (2015). Identification of female sex pheromones of Diaphania perspectalis (Lepidoptera: Crambidae) and their attractiveness to moths. Acta Entomologica Sinica, 58(10), 1081-1090. 